\title{
Effect of Partially Purified Ginger Enzyme and Commercially Available Papain on Quality of Spent Hen Meat
}

\author{
M. Muthulakshmi*, S. Vaithiyanathan, M. Muthukumar and S. Saravanakumar \\ Department of Livestock Products Technology (Meat Science), Veterinary College and \\ Research Institute, Namakkal, Tamil Nadu Veterinary and Animal Sciences University, \\ Tamil Nadu, India \\ *Corresponding author
}

\section{A B S T R A C T}

\begin{tabular}{|l|}
\hline Ke y w or d s \\
Ginger enzyme, Meat \\
quality, Microbial \\
quality, Papain, Spent \\
hen meat
\end{tabular}

\begin{abstract}
A study has been carried out to determine the partially purified ginger enzyme (GE) and commercially available papain in combination with curing agent on qualities of spent hen meat. The meat chunks were marinated for $3 \mathrm{hrs}$ at room temperature and analysed for physico-chemical and microbial qualities. The $\mathrm{pH}$ values did not show any significant difference between the treatments. Water holding capacity and cooking yield were significantly $(\mathrm{p}<0.01)$ affected by the treatments. The collagen solubility was significantly ( $p<0.01)$ affected by treatment. The shear force value of GE and papain treated samples were lower $(\mathrm{p}<0.01)$ than control spent hen meat. There was also more reduction in the number of protein bands in the samples treated with GE and papain. Microbial counts were lower ( $\mathrm{p}<0.01)$ in GE and papain treated samples. It is concluded that GE has the potential commercial applications to explore in the meat processing industry to improve the qualities of spent hen meat.
\end{abstract}

\section{Introduction}

Meat tenderness is the most important palatability attribute affecting consumer's overall eating experience (Lawrie, 1991; Dikeman, 1987). Poultry meat production has increased all over the world.

Layer chickens after about 72 weeks of laying, are sacrificed to produce meat which is available at a cheaper rate. As the animal matures, fiber hypertrophy is accompanied by maturation of the endomysium, perimysial thickness, and the formation of nonreducible cross-links between the collagen molecules
(Robins et al., 1973). The inferior quality, such as toughness in spent hen meat, is primarily due to increased cross-linking in the connective tissue of older animals (Bailey and Light, 1989). Many attempts have been made to tenderize spent hen meat (Kondaiah and Panda, 1992; Woods et al., 1997; Naveena and Mendiratta., 2001; Bhaskar et al., 2006; Vaithiyanathan et al., 2008).

Ginger is a rhizome widely used as spice in a variety of food products in general, and particularly in meat based foods. Ginger helps to enhance the flavour of the product. Ginger also has antimicrobial (Sazler, 1982) property 
that helps to extend the shelf life of a product (Kim and Lee, 1995; Syed Ziauddin et al., 1996) and also has antioxidant (Lee et al., 1986 a; Mendiratta et al., 2000) property. Ginger has also been shown to have a powerful proteolytic activity (Choi et al., 1999) and this property is useful in improving the tenderness of tough meat (Lee et al., 1986b; Naveena et al., 2004). Recently two cysteine proteases have been isolated, purified and characterized from ginger rhizome (Kim et al., 2007; Choi et al., 2000). Commercial applications of these enzymes in meat processing industry need further investigations.

Many authors have held ginger extract treated muscles for periods of $24 \mathrm{~h}$ (Mendiratta et al., 2000), 48 h (Naveena et al., 2004) or 5 days (Syed Ziauddin et al., 1995) at a low temperature of around 4o $\mathrm{C}$ and such a long period were needed as the enzyme activity is lower at refrigerated temperature and also only the crude extract was used. Bhaskar et al., (2006) used ginger powder for treatment of spent hen muscles held for $3 \mathrm{~h}$ at ambient temperature. The tenderizing effect of a protease can be relatively hastened at an ambient temperature of $29 \pm 2$ o C requiring shorter period of time provided the enzyme preparation is relatively pure enough to specifically act upon the protein to give the desired effect. The reports of Mendiratta et al., (2000); Naveena et al., (2004) and Syed Ziauddin et al., (1995) have also suggested that ginger extracts showed a greater proteolytic activity towards collagen than actomyocin and showed increased collagen solubility and reduced shear values which resulted in improved tenderness of ginger marinated meat.

Devitre and Cunningham (1985) reported that the fillets soaked in solutions of $1 \%$ sodium chloride and phosphate plus either papain, bromelin, or ficin were significantly more tender than all other treatments. Also mentioned those treated with sodium chloride plus phosphate plus papain were the most tender. Therefore the aim of the present work has been to determine combination of partially purified ginger enzyme with a curing agent on qualities of spent hen meat. The ability of papain on qualities of spent hen meat was also compared with these enzymes.

\section{Materials and Methods}

Fresh meat was obtained from spent hens slaughtered by the traditional halal method. The carcasses were deboned manually in a commercial poultry processing unit and brought to the lab within half an hour. Meat samples were stored at $4^{\circ} \mathrm{C}$ for approximately $4 \mathrm{~h}$ before treatments. Fresh meat samples were obtained separately for each of the five replications.

\section{Enzyme purification}

Ginger enzyme was purified as described by Kim et al., (2007). Briefly, fresh ginger rhizome was blended in $0.1 \mathrm{M}$ sodium phosphate buffer ( $\mathrm{pH}$ 7.0) containing $5 \mathrm{mM}$ EDTA (Ethylene Diamine Tetra Acetic acid) and STT or $10 \mathrm{~mm}$ cysteine for $3 \mathrm{~min}$. The $\mathrm{pH}$ was adjusted with $2 \mathrm{M} \mathrm{NaOH}$ to 7.0 and the mixture was stirred for $30 \mathrm{~min}$ followed by filtering through two layers of cheese cloth.

The solid residue was precipitated by ammonium sulfate (enzyme grade). After $1 \mathrm{~h}$ standing, the mixture was centrifuged at $1000 x g$ for $30 \mathrm{~min}$ at $4^{\circ} \mathrm{C}$ and supernatant was filtered through celite (Diatomaceaous earth as $\mathrm{SiO} 2$, Sigma) to remove suspended materials. Solid ammonium sulfate was added again to the filtrate to bring its concentrate to $60 \%$ saturation. After centrifugation, the resulting precipitate was suspended in a minimum amount of buffer A (30 mM sodium phosphate buffer, pH 7.0 containing $5 \mathrm{mM}$ STT and 1 
mm EDTA) and dialysed against 4 changes of 41 of $0 \mathrm{~mm}$ sodium phosphate buffer, $\mathrm{pH} 7.0$ containing $1 \mathrm{mM}$ STT and $1 \mathrm{mM}$ EDTA for $16 \mathrm{~h}$. The dialysed solution was centrifuged at $10000 x g$ for $45 \mathrm{~min}$ at $4 \mathrm{o} \mathrm{C}$. The supernatant was lyophilized. The lyoliphilized powder was used in the experiment after ascertaining its proteolytic activity.

\section{Proteolytic activity assay}

Assay was performed by incubating $2 \mathrm{ml}$ of 1 $\%$ casein solution in 0.1 acetate buffer $(\mathrm{pH}$ 5.5) containing $2 \mathrm{mM}$ EDTA with purified enzyme containing $2 \mathrm{mM}$ DTT. After 15-min incubation at $50^{\circ} \mathrm{C}, 2 \mathrm{ml}$ of $5 \%(\mathrm{w} / \mathrm{v})$ Trichloro Acetic Acid (TCA) was added to terminate the reaction followed by centrifugation at $2500 \mathrm{x}$ $\mathrm{g}$ for $10 \mathrm{~min}$. The absorbance of TCA -soluble product was measured at $280 \mathrm{~nm}$ and one unit of caseolytic activity is defined as the amount of enzyme causing an increase in absorbance by 1 unit.

\section{Experimental design}

The experimental design is presented in Table 1. Fresh meat samples were obtained separately for each of the five replications. After preparation of marinating solution the meat chunks were marinated with this solution in the ratio of 3:1 (Meat: Marinating solution) and then kept for $3 \mathrm{hrs}$ at room temperature.

\section{Analysis of meat samples}

Evaluation of meat quality parameters were made on breast muscle: $\mathrm{pH}$, Water Holding Capacity (WHC), hydroxyl proline content, collagen solubility, muscle fibre diameter, proximate composition, electrophoretic pattern of muscle and microbial quality were evaluated in raw meat after $3 \mathrm{~h}$ treatment at ambient temperature. Cooked samples were evaluated for cooking yield, $\mathrm{pH}$, shear force values and sensory attributes.
pH

The $\mathrm{pH}$ of the samples was determined by blending $10 \mathrm{~g}$ of sample with $50 \mathrm{~mL}$ of distilled water for $60 \mathrm{~s}$ in a homogenizer (MICCRA D8-Si, ART-moderne Labortechnik, Mullheim, Germany). The $\mathrm{pH}$ values were measured using a standardized electrode attached to a digital $\mathrm{pH}$ meter (Thermo Orion model 420A+, Beverly, MA).

\section{Shear Force Value}

The cooked samples were chilled at refrigerator temperature overnight and used for objective determination of tenderness (after equilibration at room temperature).

Shear Force Value (SFV) were estimated in triplicate with a Warner-Brazler blade attached to a texture analyzer. The crosshead speed was $2 \mathrm{~mm} / \mathrm{s}$. The Warner-Brazler Shear Force (WBSF) was measured in 21 cores of 1$\mathrm{cm} 3$ sizes with fibres perpendicular to the direction of the blade (Model no. 81031307, GR Elect. Mfg. Co., USA). The force required to shear the samples was recorded $\left(\mathrm{N} / \mathrm{cm}^{2}\right)$.

\section{Water holding capacity}

Water Holding Capacity (WHC) was determined according to Wardlaw, Maccaskill, and Acton (1973). Minced meat (20 g) was placed in a centrifuge tube containing $30 \mathrm{ml}$ of $0.6 \mathrm{M} \mathrm{NaCl}$ and was stirred with glass rod for $1 \mathrm{~min}$. The tube was then kept at $4 \pm 1{ }^{\circ} \mathrm{C}$ for $15 \mathrm{~min}$, stirred again and centrifuged at $3000 \mathrm{~g}$ (R-24, Remi Instruments, India) for $25 \mathrm{~min}$. The supernatant was measured and WHC was expressed in percentage.

\section{Cooking yield}

The weight of meat was recorded before and after cooking and the yield was expressed as percentage 
Cooking yield $=$ Weight of cooked meat $/$ Weight of raw meat $\times 100$

\section{Muscle fibre diameter}

Muscle fibre diameter of meat samples were assessed according to the method outlined by Jeremiah and Martin (1982). Five grams of minced meat sample was homogenized in tissue homogenizer. At low speed for two $15 \mathrm{~s}$ periods interspaced with a $5 \mathrm{~s}$ resting interval in a $30 \mathrm{ml}$ solution containing $0.25 \mathrm{M}$ sucrose and a mM EDTA to produce a slurry. One drop of the slurry was then transferred on to a glass slide and covered with a cover slip and the suspension was examined directly under a light microscope with 10X objective and eye piece equipped with calibrated micrometer. Muscle fibre diameter was measured as mean diameter of the middle and two extremities of 25 randomly selected muscle fibres and expressed in micrometer.

\section{Hydroxyproline estimation}

Hydroxyproline content of the meat sample was determined based on the procedure of Nueman and Logan (1950). Two grams meat samples were hydrolyzed with $40 \mathrm{ml}$ of $6 \mathrm{~N}$ $\mathrm{HCl}$ for $18 \mathrm{~h}$.

The hydrolysate was filtered and the volume adjusted to $50 \mathrm{ml}$ with distilled water. An aliquot was used for hydroxyproline estimation. Absorbance was measured at 540 $\mathrm{nm}$ and the hydroxyproline content was determined by referring to a standard graph. Collagen content was calculated by multiplying by 7.14 and was expressed in $\mathrm{mg} / \mathrm{g}$ tissue.

\section{Proximate composition}

Moisture, crude protein, fat and ash content of meat samples were determined by the AOAC (1995) method.

\section{Electrophoresis}

Protein samples were subjected to Sodium Dodecyl Sulphate-Polyacrylamide gel electrophoresis (Sreeramulu and Singh, 1995; Lammli, 1970) for qualitative separation of polypeptides. Five grams of minced meat was mixed with $50 \mathrm{ml}$ of $0.01 \mathrm{~N}$ sodium phosphate buffer containing $1 \%$ SDS and $1 \% \quad 2$ mercaptoethanol and incubated at $37^{\circ} \mathrm{C}$ for $2 \mathrm{~h}$ and then centrifuged at $1500 \mathrm{~g}$ for $30 \mathrm{~min}$. An aliquot of supernatant was dialysed over night at room temperature $\left(26^{\circ} \mathrm{C}\right)$ against $0.1 \mathrm{~N}$ sodium phosphate buffer containing $0.1 \% 2$ mercaptoethanol.

About $50 \mu \mathrm{l}$ of dialysed solution was mixed with equal volumes of sample buffer $\mathrm{pH} 7.4$ (consisting of $15.14 \mathrm{~g}$ Tris, 20g SDS, 200g glycerol and $0.02 \mathrm{~g}$ bromophenol blue per litre buffer) after determining the protein concentration (Lowry et al., 1951) for loading onto the staking gel. Just before the use of sample buffer $50 \mu$ 2-mercaptoethanol was added to each $0.95 \mathrm{ml}$ stock sample buffer. The gel $(1.0 \times 100 \times 1000 \mathrm{~mm})$ consists of $4.54 \mathrm{~g}$ Tris $\mathrm{pH}$ 8.8, 0.12g SDS, $29.2 \mathrm{~g}$ acryalamide, $0.8 \mathrm{~g}$ bisacrylamide per $100 \mathrm{ml}$. Ammonium persulphate $(0.0175 \mathrm{~g})$ and TEMED $(40 \mu \mathrm{l})$ was added for polymerization. The staking gel was $5 \%$ and the separating gel was $12 \%$. The samples were subjected to electrophoresis after keeping it in boiling waterbath for $3 \mathrm{~min}$ before loading onto the gels. Electrophoresis was run initially at $50 \mathrm{v}$ until the dye entered the stacking gel and then it was run at $80 \mathrm{v}$ until the dye reached $5 \mathrm{~mm}$ before the bottom of gel.

After electrophoresis, the gels were stained overnight with a staining solution containing TCA 60g, acetic acid $(60 \mathrm{ml})$, methanol (180ml) and Coomassie brilliant blue R-250 $(0.25 \%)$ in $1000 \mathrm{ml}$ distilled water and destained with $3 \% \mathrm{NaCl}$ in distilled water until the bands are clearly visible. 


\section{Microbial quality evaluation}

Three replicates from each treatment were used in microbial quality evaluation. Ten grams of meat was homogenized with $90 \mathrm{ml}$, $0.1 \%$ sterile peptone water using a Stomacher (Seeward, 400, Circulator, UK) and 10 fold serial dilutions (using $0.1 \%$ peptone water) were made before inoculating (pour plate method) into plate count agar for total plate counts (APC). For each dilution, duplicate plates were incubated at $37{ }^{\circ} \mathrm{C}$ for $48 \mathrm{~h}$ for APC (APHA, 1984).

\section{Statistical analysis}

Data on $\mathrm{pH}$, water holding capacity, collagen content, collagen solubility (\%), muscle fibre diameter, moisture, protein, fat, cooking yield, cooked $\mathrm{pH}$, shear force value, total plate count, lactic acid bacteria, yeast and mould and enterobactor variables were analyzed with treatment as the main effect using the mathematical model given below in a 1-way ANOVA procedure of SPSS 10.0 (SPSS Inc., Chicago, IL). If a value of $\mathrm{P}<0.05$ was detected, differences among means were tested separately with a Bonferroni test:

$Y i j k=\mu+D i+e i j k$

Where $\mu=$ general mean, $\mathrm{Di}=$ effect of ith treatment and Eijk $=$ random error.

\section{Results and Discussion}

In the traditional meat preparation, the condiments are used to increase the flavor and appetite. One of the most important condiments is ginger rhizome which is made into paste along with other condiments and used in the marination of the meat. In addition to that, salts of chloride and phosphates are also used to improve the functional properties of meat during comminuted meat preparation. Results of various biochemical and physicochemical parameters analyzed are presented in Table 2.

\section{pH and WHC}

The $\mathrm{pH}$ values varied from 6.08 to 6.18 . There was no significant difference in the $\mathrm{pH}$ of the treatments. It is in agreement with observation by Naveena and Mendiratta (2004) in buffalo meat treated with ginger extract, but in disagreement with result of Naveena and Mendiratta 2001 with ginger extract and Khanna and Panda (2007) with papain treated spent hen meat. They have observed that higher $\mathrm{pH}$ was in treated samples. This result may be due to tripoly phosphate content in all the treatments, although the value was slightly higher for ginger treated sample compared to control.

Water Holding Capacity (WHC) ranged from 38.70 to 47.00 (\%) which were significantly (p $<0.01$ ) different between the samples (Table 2). GE treated sample had higher WHC than control which are in agreement with Naveena and Mendiratta (2001). WHC of papain treated sample was in between the broiler and ginger treated samples. Khanna and Panda (2007) reported increased WHC of spent hen meat treated with papain and Naveena $e t$ al., (2004) reported similar results in buffalo meat treated with ginger extract. Compared to broiler meat, the treated sample had lower WHC, which may be due to meat from very old animals that have lower WHC (Syed Ziauddin, 1994).

\section{Collagen content and solubility}

The total collagen content which is an important parameter in the spent hen meat varied from 2.42 to $5.73(\mathrm{mg} / \mathrm{g})$ (Table 2). There was highly significant ( $\mathrm{p}<0.001)$ difference between the collagen content of broiler and spent hen meat. Spent hen meat having higher collagen content, Bailey (1984) 
also reported that increased collagen content and cross linkages in spent hen meat. There were no significant difference between collagen content of control and treated spent hen meat samples. The collagen solubility (\%) ranged from 17.10 to 21.37 .

A highly significant $(\mathrm{p}<0.01)$ difference between the collagen solubility of spent hen meat, spent hen meat treated with proteolytic enzymes and broiler meat was observed. It is agreed with results of spent hen meat treated with Ginger Extract by Naveena and Mendiratta (2001). The Collagen solubility were higher $(\mathrm{p}<0.01)$ for GE and papain treated samples compared to untreated. Increase in collagen solubility by GE treatment was also observed by Thompson et al., (1973) and Naveena and Mendiratta (2001).

They reported that proteolytic activity of ginger protease on collagen was many times greater than that on actomyosin and the combined proteolysis of these two muscle proteins resulted in significantly more tender meat. The solubility of connective tissue rather than total amount of connective tissue is more highly associated with sensory characteristics (Crouse et al., 1985).

\section{Proximate composition}

The moisture content of broiler chicken muscle was higher $(\mathrm{p}<0.01)$ than spent hen meat and the moisture varied from 77.62 to 76.51 (\%). Chuaynukool et al., (2007) also reported the same. But moisture content of the treated samples were higher $(\mathrm{p}<0.01)$ than control. The protein content of meat sample varied from 19.43 to $19.63(\%)$ and the protein content of the sample had no significant difference. However, the broiler samples had higher $(\mathrm{p}<0.01)$ fat content compared to both control and treated spent hen meat and the fat content varied from 2.70 to $1.72(\%)$. This may possibly be due to feeding of broilers with high energy diet to attend higher growth rates, while the spent hen selected were almost at the end of their lifespan.

\section{Muscle fibre diameter and electrophoretic pattern of muscle protein}

The muscle fibre diameter of untreated and treated samples varied 17.85 to $23.19 \mu \mathrm{m}$ (Table 2). The diameter of muscle fibres were slightly higher $(\mathrm{p}<0.01)$ for treated samples compared to controls. Higher values of muscle fibre diameter in GE treated samples compared to control were also reported by Naveena et al., (2001) but were contrast to findings of Tuma et al., (1962) who reported that fibre diameter increases and tenderness decreases with increasing animal age.

However, the correlation between these two variables differed greatly with age of animals. The average diameter of chicken muscle white fiber has been reported to be 38-46 $\mu \mathrm{m}$ (Smith and Fletcher, 1988) and 26-28 $\mu \mathrm{m}$ (Wattanachant et al., 2005). The differences in muscle fiber diameter were possibly due to the difference in age, rate of rigor on set and degree of sarcomere shortening (Wattanachant et al., 2005). The fiber diameter of broiler chicken muscle was larger than spent hen muscles.

The electrophoretic pattern of control and treated samples after $3 \mathrm{~h}$ treatment presented in Figure 1 and Table 3. The treated muscles had fewer protein bands, i.e., 3 and 2 bands for GE and papain treated muscles respectively as compared to 7 bands for broiler meat and spent hen meat samples. The similar results was observed by Naveena and Mendiratta (2001) in ginger extract treated spent hen meat, but sample treatment was for 48h and Bhaskar et al., (2006) in ginger powder treated spent hen sample treatment was for $3 \mathrm{~h}$. 
Table.1 Experimental design

\begin{tabular}{|c|c|c|c|c|}
\hline Curing ingredients & $\begin{array}{c}\text { Broiler } \\
\text { meat }\end{array}$ & $\begin{array}{l}\text { Control } \\
\text { (spent hen } \\
\text { meat) }\end{array}$ & $\begin{array}{l}\text { Ginger enzyme } \\
\text { (spent hen } \\
\text { meat) }\end{array}$ & $\begin{array}{l}\text { Papain (spent } \\
\text { hen meat) }\end{array}$ \\
\hline Water & $1000 \mathrm{ml}$ & $1000 \mathrm{ml}$ & $1000 \mathrm{ml}$ & $1000 \mathrm{ml}$ \\
\hline $\begin{array}{l}\text { Ginger enzyme powder } \\
(0.5 \%)\end{array}$ & - & - & $5 \mathrm{~g}$ & - \\
\hline Papain powder $(0.5 \%)$ & - & - & -- & $5 \mathrm{~g}$ \\
\hline $\begin{array}{l}\text { Sodium tripoly phosphate } \\
(0.5 \%)\end{array}$ & $5 g$ & $5 g$ & $5 g$ & $5 g$ \\
\hline Salt (5\%) & $50 \mathrm{~g}$ & $50 \mathrm{~g}$ & $50 \mathrm{~g}$ & $50 \mathrm{~g}$ \\
\hline
\end{tabular}

Table.2 Effect of partially purified ginger enzyme and commercially available papain treatment on physico-chemical parameters of raw and cooked spent hen meat

\begin{tabular}{|c|c|c|c|c|c|}
\hline Parameter & $\mathbf{A}$ & B & C & D & $\begin{array}{l}\text { Level of } \\
\text { significance }\end{array}$ \\
\hline \multicolumn{6}{|l|}{ Raw meat } \\
\hline$\overline{\mathrm{pH}}$ & $6.09 \pm 0.01$ & $6.08 \pm 0.05$ & $6.18 \pm 0.01$ & $6.12 \pm 0.04$ & ns \\
\hline $\begin{array}{l}\text { Water holding } \\
\text { capacity }(\%)\end{array}$ & $47.00 \pm 0.17^{\mathrm{c}}$ & $38.70 \pm 0.04^{\mathrm{a}}$ & $43.06 \pm 0.07^{\mathrm{bc}}$ & $41.20 \pm 0.09^{\mathrm{ab}}$ & $* *$ \\
\hline $\begin{array}{l}\text { Collagen content } \\
(\mathrm{mg} / \mathrm{g})\end{array}$ & $2.42 \pm 0.23^{\mathrm{a}}$ & $5.12 \pm 0.44^{b}$ & $5.73 \pm 0.15^{b}$ & $5.16 \pm 0.13^{b}$ & $* * *$ \\
\hline $\begin{array}{l}\text { Collagen solubility } \\
(\%)\end{array}$ & $21.37 \pm 0.75^{b}$ & $17.10 \pm 0.58^{\mathrm{a}}$ & $20.00 \pm 0.61^{b}$ & $19.71 \pm 0.62^{b}$ & $* *$ \\
\hline $\begin{array}{l}\text { Muscle fibre } \\
\text { diameter }(\mu \mathrm{m})\end{array}$ & $23.19 \pm 0.37^{\mathrm{c}}$ & $17.85 \pm 0.48^{\mathrm{a}}$ & $20.88 \pm 0.46^{b}$ & $20.08 \pm 0.76^{b}$ & $* *$ \\
\hline Moisture & $77.62 \pm 0.062^{b}$ & $76.51 \pm 0.163^{\mathrm{a}}$ & $77.36 \pm 0.626^{b}$ & $77.49 \pm 0.108^{b}$ & $* *$ \\
\hline Protein & $19.63 \pm 0.14$ & $19.43 \pm 0.19$ & $19.60 \pm 0.40$ & $19.53 \pm 0.61$ & ns \\
\hline Fat & $2.70 \pm 0.12^{b}$ & $1.72 \pm 0.02^{\mathrm{a}}$ & $1.80 \pm 0.09^{\mathrm{a}}$ & $1.73 \pm 0.03^{\mathrm{a}}$ & $* *$ \\
\hline \multicolumn{6}{|l|}{ Cooked meat } \\
\hline Cooking yield $(\%)$ & $75.74 \pm 0.68^{b}$ & $70.83 \pm 0.49^{\mathrm{a}}$ & $73.63 \pm 1.51^{\mathrm{ab}}$ & $72.88 \pm 0.63^{\mathrm{ab}}$ & $*$ \\
\hline Cooked meat pH & $6.14 \pm 0.02^{\mathrm{a}}$ & $6.13 \pm 0.04^{\mathrm{a}}$ & $6.23 \pm 0.01^{b}$ & $6.16 \pm 0.01^{\mathrm{ab}}$ & $*$ \\
\hline $\begin{array}{l}\text { Shear force value } \\
\left(\mathrm{N} / \mathrm{cm}^{2}\right)\end{array}$ & $12.66 \pm 1.32^{\mathrm{a}}$ & $21.46 \pm 1.29^{b}$ & $12.85 \pm 0.05^{\mathrm{a}}$ & $13.67 \pm 0.82^{a}$ & $* *$ \\
\hline
\end{tabular}

$\mathrm{A}=\mathrm{Broiler}$ meat, $\mathrm{B}=$ Spent hen meat, $\mathrm{C}=$ Spent hen meat + ginger enzyme, $\mathrm{D}=$ Spent hen meat + papain 
Table.3 Effect of partially purified ginger enzyme and commercially available papain treatment on protein disintegration of spent hen meat

\begin{tabular}{|l|c|c|c|c|}
\hline Protein band number & A & B & C & D \\
\hline $\mathbf{1}$ & 86.64 & 86.64 & & \\
\hline $\mathbf{2}$ & 72.97 & 76.39 & & \\
\hline $\mathbf{3}$ & 49.05 & 55.89 & & \\
\hline $\mathbf{4}$ & 35.38 & 38.80 & & \\
\hline $\mathbf{5}$ & 11.46 & 18.29 & 28.55 & 25.13 \\
\hline $\mathbf{6}$ & 4.62 & 4.62 & 4.62 & 25.13 \\
\hline 7 & & & $\begin{array}{c}\text { Low mwt } \\
\text { peptides }\end{array}$ & $\begin{array}{c}\text { Low mwt } \\
\text { peptides }\end{array}$ \\
\hline
\end{tabular}

$\mathrm{A}=$ Broiler meat, $\mathrm{B}=$ Spent hen meat, $\mathrm{C}=$ Spent hen meat + ginger enzyme, $\mathrm{D}=$ Spent hen meat + papain

Table.4 Effect of partially purified ginger enzyme and commercially available papain treatment on microbial qualities of spent hen meat

\begin{tabular}{|l|l|l|l|l|l|}
\hline Parameter & A & B & C & D & $\begin{array}{l}\text { Level of } \\
\text { significance }\end{array}$ \\
\hline Total plate count & $4.91 \pm 0.00^{\mathrm{b}}$ & $4.49 \pm 0.01^{\mathrm{b}}$ & $3.61 \pm 0.00^{\mathrm{a}}$ & $3.88 \pm 0.01^{\mathrm{a}}$ & $* *$ \\
\hline Lactic acid bacteria & $1.95 \pm 0.00^{\mathrm{d}}$ & $1.78 \pm 0.01^{\mathrm{c}}$ & $1.48 \pm 0.01^{\mathrm{a}}$ & $1.73 \pm 0.04^{\mathrm{b}}$ & $* *$ \\
\hline Yeast and mould & $1.81 \pm 0.00^{\mathrm{d}}$ & $1.76 \pm 0.01^{\mathrm{c}}$ & $1.50 \pm 0.01^{\mathrm{a}}$ & $1.61 \pm 0.00^{\mathrm{b}}$ & $* *$ \\
\hline Enterobactor & $1.73 \pm 0.04^{\mathrm{a}}$ & $2.12 \pm 0.03^{\mathrm{c}}$ & $1.94 \pm 0.01^{\mathrm{b}}$ & $2.07 \pm 0.03^{\mathrm{c}}$ & $* *$ \\
\hline
\end{tabular}

$\mathrm{A}=\mathrm{Broiler}$ meat, $\mathrm{B}=$ Spent hen meat, $\mathrm{C}=$ Spent hen meat + ginger enzyme, $\mathrm{D}=$ Spent hen meat + papain ${ }^{1}=\log _{10} / \mathrm{g}$; $* \mathrm{P}<0.05 ; * * \mathrm{P}<0.01$

Fig.1 Effect of partially purified ginger enzyme and commercially available papain treatment on electrophoretic pattern of muscle proteins after holding for $3 \mathrm{~h}$ at room temperature

\begin{tabular}{|c|c|c|c|c|c|c|}
\hline & & A & B & $\mathrm{C}$ & $\mathrm{D}$ & $\mathrm{E}$ \\
\hline & $97.4 \mathrm{kDa}$ & & & & & \\
\hline$\rightarrow$ & & $=$ & & & & \\
\hline & $66.0 \mathrm{kDa}$ & & & & & \\
\hline$\rightarrow$ & & & & & & \\
\hline & $43.0 \mathrm{kDa}$ & & & & & \\
\hline$\rightarrow$ & & & & & & \\
\hline & $29.0 \mathrm{kDa}$ & & & & & \\
\hline$\longrightarrow$ & & & & & & \\
\hline & J.1nua & & & & & \\
\hline$\rightarrow$ & & & & & & \\
\hline
\end{tabular}

A: Protein marker B: Broiler meat C: Spent hen meat D: Spent hen meat + ginger E: Spent hen meat+ papain 
The less number of bands in treated samples were not prominent as compared to control samples. It suggested that there was an increased proteolysis of muscle proteins in GE and papain treated samples, as shown by reduction in the number of protein bands. There was also more reduction in the number of bands in the samples treated with papain compared with GE samples, which may be due to high purity of papain. Reduction in the number of protein bands in GE and papain treated samples may also be due to proteolysis of high molecular weight proteins into a number of low-molecular weight peptides, which may overlap each other and get accumulated at the bottom of the gel.

\section{Cooking yield, cooked meat $\mathrm{pH}$ and shear force value}

The cooking yield did not vary much between the control and treated samples. But there was a significant $(\mathrm{p}<0.05)$ difference was observed in cooking yield between broiler meat and spent hen meat. However the cooked meat $\mathrm{pH}$ showed differences between the control and GE treated samples. The shear force values varied from 12.66 to 21.46 $\left(\mathrm{N} / \mathrm{cm}^{2}\right)$ (Table 2).

The shear force value of GE and papain treated samples were lower $(\mathrm{p}<0.01)$ than control spent hen. Thompson et al., (1973); Lee et al., (1986); Syed Ziauddin et al., (1995) and Naveena and Mendiratta (2001) also observed the reduction $(\mathrm{p}<0.05)$ in shear force values in ginger extract-treated samples. Bhaskar et al., (2006) also observed that in ginger powder treated samples the shear force value was less as compared to control. Khanna and Panda (2007) also reported that reduction $(p<0 \bullet 05)$ in shear force values of papain treated spent hen meat. The shear force value of $\mathrm{GE}$ and papain treated samples were almost closer to broiler meat. Devitre and Cunningham (1985) observed that fillets treated with sodium chloride plus sodium tripolyphosphate plus papain were the most tender. The decrease in shear force values and the increase in collagen solubility in ginger extract treated samples were quite similar to papain treated sample.

\section{Microbial quality}

The microbial quality of experimental samples showed somewhat a clear picture. The Total plate counts varied from 3.61 to $4.61(\log 10 / \mathrm{g})$, Lactic acid bacterial counts varied from 1.48 to $1.95(\log 10 / \mathrm{g})$, Yeast and mould counts varied from 1.50 to 1.81 $(\log 10 / \mathrm{g})$ and Enterobactor counts varied from 1.73 to $2.12(\log 10 / g)$ (Table 4$)$.

\section{Means bearing uncommon superscripts within rows differ significantly for all tables}

Total plate count, Lactic acid bacterial count, Yeast and mould and Enterobactor count were lower $(\mathrm{p}<0 \bullet 01)$ in GE and papain treated samples. However, the difference in the counts was below 1 log unit, a minimum requirement or significant difference between samples (Gill and McGinnis, 1999) in the microbial counts except the total plate counts. The difference of $1 \log$ unit was observed in the total plate counts of samples treated GE and papain.

However this difference of $1 \log$ unit was not observed in the differential microbial counts. Mascolo et al., (1989) reported that the hydro ethanolic extract of ginger have potent antimicrobial activity against Gram negative and Gram positive bacteria. Sazler (1982) reported that inhibition of E.coli, E.faecalis, S.typhimurium, S.aureus, B.cerus and C. perfringes by the use of ginger extracts in meat products. Mendiratta et al., (2010) recommended ginger extract when meat curry is to be used after storage at refrigerated 
temperature; the magnitudes of changes during storage were less in ginger-treated chunks. Sudharshan et al., (2011) also reported that the essential oil of ginger significantly decreased the bacterial count, whereas aqueous extract of ginger had no much effect in chicken meat. This might be due to the fact that active principle of ginger di-allyl-di-sulphide and gingerols are insoluble in water and are extracted only during solvent extraction process (Shelef, 1983). Emeruwa (1982) and Seenivasan et al., (2010) reported the antimicrobial effect of papain. In the present study also, the solvent extracted enzyme has shown the antimicrobial effect in the treated sample.

The use of condiments in marinating the meat to improve the eating quality is an important culinary art in the meat preparation. The commercial application of the purified form of chemical compound from the condiments requires authentication in the meat processing laboratory. The results from the present study have suggested that treatment with partially purified enzyme from ginger rhizome have increased the collagen solubility, the protein degradation (myofibrillar protein) and reduced the shear force value as similar to that of the treatment with commercially available papain of spent hen meat. Further the results have suggested that partially purified enzyme from ginger rhizome reduced the total plate (microbial) counts of spent hen meat as similar to that of the treatment with commercially available papain. It is concluded that ginger enzyme has the potential commercial applications to explore in the meat processing industry to improve the qualities of spent hen meat.

\section{Acknowledgements}

Authors are thankful to the Director, National Research Centre on Meat, Hyderabad for providing necessary facilities.

\section{References}

A.P.H.A. (1984). In M. L. Speck, Ed., Compendium of methods for the microbiological examination of foods, 2nd ed. Washington DC: American Public Health Association.

AOAC. (1995). Official Methods of Analysis, (16th Ed.). Washington, DC, Assoc. of Official Analytical Chemists.

Bailey, A. J. and Light N. D.1989. The Connective Tissue of Meat and Meat Products. Elsevier Applied Science, London.

Bailey, A.J. (1984). The chemistry of intramolecular collagen, in: BAILEY, A.J. Ed., Recent Advances in Chemistry of Meat. 17-22. London, the Royal Society of Chemistry.

Bhaskar, N., Sachindra, N. M., Modi, V. K., Sakhara, P. Z. and Mahendrakar, N. S. (2006). Preparation of proteolytic activity rich ginger powder and evaluation of its tenderizing effect on spent hen muscle. J. Muscle Foods. 17, 174-184.

Choi, K.H., and Laursen, R.A. (2000). Aminoacid sequence and glycan structures of cysteine proteases with proline specificity from ginger rhizome Zingiber officinale European Journal of Biochemistry. 267, 1516-1526.

Choi, K.H., Laursen, R.A. and Allen, K.N.1999. The 2.1 A structures of cysteine proteases with proline specificity from ginger rhizome, Zingiber officinale. Biochemistry -US 38, 11624-11633.

Chuaynukool, K., Wattanachant, S., and Siripongvutikorn, S. 2007. Chemical and properties of raw and cooked spent hen, broiler and Thai indigenous chicken muscles in mixed herbs acidified soup (Tom Yum). J. Food Tech., 5,180-186.

Crouse, J. D., Cross, H. R., and Seideman, S. C. (1985). Effects of sex condition, genotype, diet and carcass electrical stimulation on the collagen content and palatability of two bovine muscles. J. Anim. Sci. 60, 1228. 
Devitre H. A., and Cunningham, F. E. (1985). Tenderization of Spent Hen Muscle Using Papain, Bromelin, or Ficin Alone and in Combination with Salts. Poult Sci. 64, 1476-1483.

Dikeman, M. E. (1987). Fat reduction in animals and the effects on palatability and consumer acceptance of meat products. Proc. Recip. Meat Conf. 40, 93.

Emeruwa, A. C. (1982). Antibacterial Substance from Carica papaya Fruit Extract. J. Nat. Prod. 45, 123 -127.

Gill, C. O., and McGinnis, J. C. (1999). Improvement of hygienic performance of the hindquarters skinning operations at a beef packing plant. Int. J. of Food Microbiol. 51, 123-132.

Jeremiah, L.E and Martin, A.H. (1982).Effect of prerigor chilling and freezing and subcutaneous fat cover upon the histological and shear properties of bovine longissimus dorsai muscle. Canadian journal of animal science, 62, 353-361.

Khanna, N., and Panda, P.C.(2007). Effect of papain on tenderization and functional properties of spent hen meat cuts. Indian J.Anim.Res.41, 55-58.

Kim K.J., and Lee Y.B. (1995). Effect of ginger rhizome extract on tenderness and shelf life of pre-cooked lean beef. Journal of Korean Society of Food Science, 11, 119121.

Kim, J.K., Kim, Y., Na, K.M., Surh, Y.J., and Kim, T.Y. (2007). [6]-Gingerol prevents UVB-induced ROS production and COX2 expression in vitro and in vivo. Free Radical Research. 41, 603-614.

Kondaiah, N., and Panda, B. (1992). Processing and utilization of spent hens. World Poult. Sci. 48, 255-265.

Laemmli, U.K. (1970). Cleavage of structural proteins during the assembly of head or bacteriophage T4. Nature. 227, 680-685.

Lawrie, R.A. (1991). Lawrie Meat Science (5th Ed.) Pergamon Press, Oxford

Lee, Y.B., Sehnert, D.J., and Ashmore, C.R. (1986a). Antioxidant property in ginger rhizome and its application to meat products. Journal of Food Science, 51, 20-23.

Lee, Y.B., Sehnert, D.J., and Ashmore, C.R. (1986b). Tenderization of meat with ginger rhizome protease. Journal of Food Science, 51, 1558-1559.

Mascolo, N., Jain, R.., Jain, S.C., and Capasso, F. (1989). Ethnopharmacologic investigation of ginger. Journal of Ethnopharmacology, 27,129-140.

Mendiratta S.K., Anjaneyulu, A.S.R., Lakshmanan, V., Naveena, B.M., and Bisht, G.S. (2000). Tenderizing and antioxidant effect of ginger extract on sheep meat. Journal of Food Science and Technology, 37, 565-570.

Mendiratta, S.K., Sharma, B.D., Narayan, R. Mane, B.G. (2010). Effect of proteolytic enzyme treatments and pressure cooking on quality of spent sheep meat curry. Journal of Muscle Foods, 21, 685-701.

Naveena B.M., and Mendiratta S.K. (2001).Tenderization of spent hen meat using ginger extract. British Poultry Science, 42,344-350.

Naveena B.M., Mendiratta, S.K., and Anjaneyulu A.S.R. (2004). Tenderization of buffalo meat using plant proteases from Cucumis trigonus Roxb (Kachri) and Zingiber officinale roscoe (Ginger rhizome). Meat Science, 68, 363-369.

Naveena B.M., Mendiratta, S.K., and Anjaneyulu, A.S.R. (2000). Use of ginger extract for production of cured and smoked product from spent hen meat. Indian Journal of Poultry Science, 35, 291-296.

Nueman, R.E., and Logan, M.A. (1950). Determination of hydroxyproline content. Journal of Biological Chemistry, 184, 299.

Robins, S. P., Shimokomaki, M., and Bailey, A. J. (1973). The Chemistry of the Collagen Cross-Links age-related changes in the reducible components of intact bovine collagen fibres. Biochem. J. 131, 771-780

Salzer U.J. (1982). Antimicrobial action of some spice extracts and mixtures. Fleischwirschaft. 62 (7), 885 -887. 
Seenivasan, R., Roopa, L., and Geetha, S. (2010). Investigations on purification, characterization and antimicrobial activity of enzyme papain from Carica papaya Linn. Journal of Pharmacy Research, 3(5), 1092-1095.

Shelef, L.A. (1983). Antimicrobial effects of spices. Journal of Food Safety, 6, 29-44

Smith, D. P., and D. L. Fletcher. (1988). Chicken breast muscle fiber type and diameter as influenced by age and intramuscular location. Poult. Sci. 67:908-913.

Sreeramulu, G., and Singh, N.K. (1995). Destaining of Commassie brilliant blue R-250 stained polyacrylamide gels with sodium chloride solutions. Electrophoresis. 16, 362-365.

Sudharshan, S., Fairoze, M.N., Prabha, R., Rathnamma, D., and Prasath C.R. (2011). Ginger extract as an antimicrobial agent: A case study in chicken meat. J. Meat., Sci., 7, 37-41.

Syed Ziauddin K. (1994). Observations on some chemical and physical characteristics of buffalo meat. Meat Science, 37, 103.

Syed Ziauddin, K., Rao, D. N., and Amla, B. L. (1995). Effect of lactic acid, ginger extract and sodium chloride on electrophoretic pattern of buffalo muscle proteins. J. Food Sci. Tec Technol. 32,224-226.

Syed Ziauddin, K., Subbarao, H., and Nadeem, F. (1996). Effect of organic acids and spices on quality and shelf life of meats at ambient temperature. J. Food Sci. Tech. Mys. 33, 255-258.

Thompson, E.H., Wolf, I.D., and Allen, C.E. (1973). Ginger rhizome: A new source of proteolytic enzyme. Journal of Food Science, 38, 652-655.

Tuma, H.J., Venable, J.H., Wuthier, P.R., and Henrickson, R.L. (1962). Relationship of fiber diameter to tenderness and meatiness as influenced by bovine age. Journal of Animal Science, 21, 33-36.

Vaithiyanathan, S., Naveena, B. M., Muthukumar, M., Girish,P. S., Ramakrishna, C., Sen, A. R., and Babji, Y. (2008). Biochemical and Physicochemical Changes in Spent Hen Breast Meat during Postmortem Aging. Poult. Sci. 87(1), 180-186.

Wardlaw, F.B., Maccaskill, L.H. and Acton, J.C. (1973) Effect of postmortem muscle changes in poultry meat loaf properties. Journal of Food Science, 38, 421-424.

Wattanachant, S., Benjakul, S., and Ledward, D. A. (2005). Microstructure and Thermal Characteristics of Thai Indigenous and Broiler Chicken Muscles. Poultry Science 84,328-336.

Woods, K. L., Rhee, K. S., and Sam, A. R. (1997). Tenderizing spent fowl meat with calcium chloride.4. Improved oxidative stability and effects of additional aging. Poult. Sci. 76, 548-551.

\section{How to cite this article:}

Muthulakshmi, M., S. Vaithiyanathan, M. Muthukumar and Saravanakumar, S. 2018. Effect of Partially Purified Ginger Enzyme and Commercially Available Papain on Quality of Spent Hen Meat. Int.J.Curr.Microbiol.App.Sci. 7(10): 1734-1745. doi: https://doi.org/10.20546/ijcmas.2018.710.199 